\title{
KHAWARIJ; SEJARAH DAN PERKEMBANGANNYA
}

\author{
Saleh*
}

Abstrak

Ketidak puasan atas terjadinya tahkim antara Ali dan Mu'awiyah telah menyulut sebagian dari tentara Ali untuk memisahkan diri dan melakukan pemberontakan. Inilah generasi pertama Khawarij lahir. Mereka menolak hasil dari tahkim yang menyebabkan kalahnya Ali dan turunnya dari jabatan sebagai Khalifah. Dengan jumlah sekitar dua belas ribu orang akhirnya mereka melakukan pemberontakan. Khawarij bersikap bermusuhan terhadap Ali maupun terhadap Mu'awiyah. Mereka beranggapan, orang-orang Islam selain mereka sendiri adalah kafir dan halal darahnya serta kekayaannya. Dalam tulisan ini akan diurai sejarah serta perkembangan aliran Khawarij serta sektesekte yang ada didalamnya dan ajaran pokok yang dianutnya.

Kata Kunci : Khawarij, Tahkim, Pemikiran Islam, Perang Shiffin

\section{Pendahuluan}

Peradaban yang telah dibangun umat Islam telah mengalami banyak likuliku, ketidakpuasan manusia yang selalu merasuki membuat terjadinya pergolakanpergolakan dalam perjalanannya. Kegagalan di perang Shiffin telah menimbulkan akibat yang sangat buruk di kalangan tentara khalifah Ali bin Abi Tholib. Ada sebagian dari mereka melepaskan diri dari tentara Ali dan memberontak untuk memerangi Ali dan Mu'awiyah. Golongan ini menamakan dirinya Khawarij.

Ketidak puasan atas terjadinya tahkim antara Ali dan Mu'awiyah telah menyulut sebagian dari tentara Ali untuk memisahkan diri dan melakukan pemberontakan. Inilah generasi pertama Khawarij lahir. Mereka menolak hasil dari tahkim yang menyebabkan kalahnya Ali dan turunnya dari jabatan sebagai Khalifah. Dengan jumlah sekitar dua belas ribu orang akhirnya mereka melakukan pemberontakan. Khawarij bersikap bermusuhan terhadap Ali maupun terhadap Mu'awiyah. Mereka beranggapan, orang-orang Islam selain mereka sendiri adalah kafir dan halal darahnya serta kekayaannya.

Dalam makalah akan diuraikan sejarah serta perkembangan aliran Khawarij serta sekte-sekte yang ada didalamnya dan ajaran pokok yang dianutnya. 
A. Faktor - faktor Timbulnya Perbedaan Aliran dalam Aqidah Islam

Menurut Harun Nasution, persoalan yang pertama kali timbul dalam Islam adalah persoalan dalam bidang politik bukannya dalam bidang teologi. Tapi persoalan politik segera meningkat menjadi persoalan teologi sehingga muncul berbagai aliran teologi. ${ }^{1}$ Jadi, menurut Harun Nasution penyebab timbulnya berbagai aliran teologi dalam Islam adalah politik. Namun apabila dikaji lebih seksama, munculnya aliran-aliran teologi dalam Islam tidak mesti disebabkan oleh faktor politik. Ayat-ayat Al-Qur'an sendiri sangat memungkinkan untuk memunculkan perbedaan adanya pendapat ketika ditafsirkan oleh orang yang memiliki latar belakang sosial dan budaya yang berbeda yang pada akhirnya dapat melahirkan berbagai aliran teologi.dengan kata lain, tidak semua aliran kalam ditimbulkan oleh persoalan politis,namun ada beberapa aliran kalam yang memang berawal dari persoalan teologis. ${ }^{2}$

\section{B. Pengertian Aliran Khawarij}

Secara etimologi kata khawarij berasal dari bahasa Arab, yaitu kharaja yang berarti keluar, mucul, timbul atau memberontak. Berdasarkan pengertian etimologi ini pula, khawarij berarti setiap muslim yang ingin keluar dari kesatuan umat Islam. ${ }^{3}$

$$
\text { Adapun khawarij dalam }
$$

terminology ilmu kalam adalah suatu sekte/kelompok/aliran pengikut Ali bin Abi Thalib yang keluar meninggalkan barisan karena ketidaksepakatan terhadap keputusan Ali yang menerima arbitrase (tahkim), dalam perang siffin pada tahun 37 H/657 M, dengan kelompok bughat (pemberontak) Muawiyah bin Abi Sufyan perihal persengketaan khilafah. ${ }^{4}$

Harun Nasution menyebutkan bahwa nama Khawarij berasal dari kata Kharaja yang berarti keluar. Nama itu sendiri diberikan kepada mereka karena mereka keluar dari barisan Ali. ${ }^{5}$ Tetapi ada pendapat lain mengatakan pemberian nama itu didasarkan atas ayat Al-Qur'an surat an-Nisa': 100 menyebutkan:

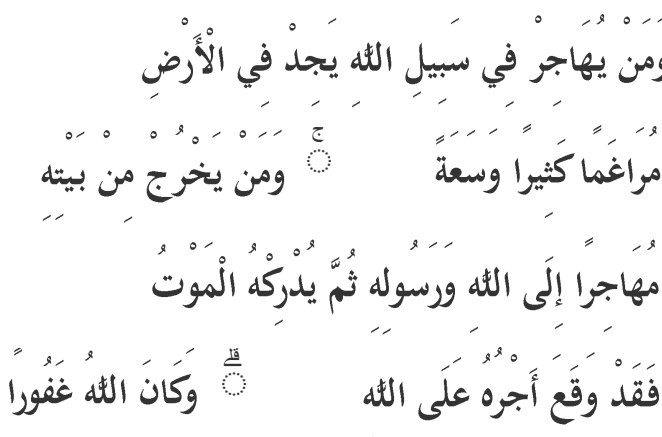

رحيما

Barangsiapa berhijrah di jalan Allah, niscaya mereka mendapati di muka bumi ini tempat hijrah yang luas dan rezki yang banyak. Barangsiapa keluar dari rumahnya dengan maksud berhijrah kepada Allah dan 
Rasul-Nya, kemudian kematian menimpanya (sebelum sampai ke tempat yang dituju), maka sungguh telah tetap pahalanya di sisi Allah. Dan adalah Allah Maha Pengampun lagi Maha Penyayang. (QS. An-Nisaa': 100)

Dengan demikian kaum Khawarij memandang diri mereka sebagai orang yang meninggalkan rumah dan kampung halamannya untuk mengabdikan diri kepada Allah dan Rasul-Nya. Kaum khawarij kadang-kadang juga menamakan golongan mereka kaum Syurah, artinya kaum yang mengorbankan dirinya untuk kepentingan keridhoan Allah. Sebagaimana tercantum dalam surat alBaqarah ayat 207:

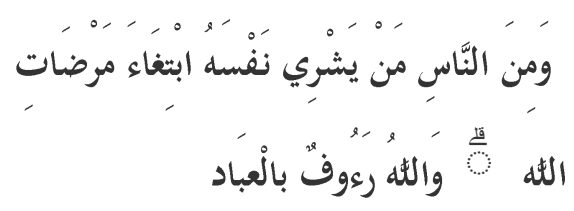

Dan di antara manusia ada orang yang mengorbankan dirinya karena mencari keridhaan Allah; dan Allah Maha Penyantun kepada hamba-hamba-Nya. (QS. Al-Baqarah: 207).

Dan, mereka juga sering disebut Haruriyah dari kata Harura yaitu nama desa yang terletak di dekat Kufa di Irak. Di tempat inilah mereka berkumpul setelah memisahkan diri dari Ali berjumlah dua belas ribu orang dengan memilih Abdullah Ibn wahab al-Rasid menjadi imam sebagai ganti dari Ali Ibn Abi Thalib. ${ }^{6}$

\section{Ciri - ciri Kaum Khawarij}

1. Mudah mengkafirkan orang yang tidak segolongan dengan mereka, walaupun orang tersebut adalah penganut agama Islam.

2. Islam yang benar adalah Islam yang mereka pahami dan amalkan. Islam sebagaimana yang dipahami dan diamalkan golongan Islam lain tidak benar.

3. Orang-orang Islam yang tersesat dan telah menjadi kafir itu perlu dibawa kembali ke Islam yang sebenarnya, yaitu Islam seperti yang mereka pahami dan amalkan.

4. Karena pemerintahan dan ulama yang tidak sepaham dengan mereka adalah sesat, maka mereka memilih imam dari golongan mereka sendiri. Imam dalam arti pemuka agama dan pemuka pemerintahan.

5. Mereka bersikap fanatik dalam paham dan tidak segan-segan menggunakan kekerasan dan pembunuhan untuk mencapai tujuan mereka. ${ }^{7}$

\section{Sebab-sebab Munculnya Aliran Khawarij}


Asal mulanya kaum Khawarij adalah orang yang mendukung Sayyidina Ali. Akan tetapi, akhirnya mereka membencinya karena dua anggota lemah dalam menegakkan kebenaran, mau menerima tahkim yang sangat mengecewakan, sebagaimana mereka juga membenci $\mathrm{Mu}^{\prime}$ awiyah karena melawan Sayyidina Ali Khalifah yang sah. ${ }^{8}$

Munculnya nama golongan Khawarij adalah setelah peristiwa tahkim, yaitu sebagai upaya menyelesaikan peperangan antara Ali bin Abi Thalib disatu pihak dengan $\mathrm{Mu}^{\prime}$ awiyah dipihak lain. Peperangan kedua pihak itu terjadi disebabkan $\mathrm{Mu}^{\prime}$ awiyah pada akhir $37 \mathrm{H}$, menolak mengakui kekholifahan Ali bin Abi Thalib. Karena setelah Ali bin Abi Thalib memindahkan ibu kotanya ke alKufah9. Setelah adanya penolakan tersebut

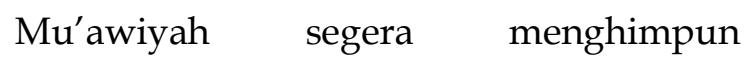
pasukannya untuk menghadapi kekuatan Ali sehingga pecahlah peperangan Siffin pada tahun $37 \mathrm{H} / 658 \mathrm{M}$.

Dalam peperangan ini tentara Ali di bawah pimpinan Malik al-Asytar hamper mencapai titik kemenangannya, yaitu tentara Ali dapat mendesak tentara Mu'awiyah. Dan, melihat pasukannya terdesak mundur 'Amru bin Asy panglima tertinggi pasukan Mu'awiyah memerintahkan pasukannya mengangkat tinggi-tinggi al-Qur'an dengan ujung 28 tombak sambil berkata al-Qur'an yang akan menjadi hakim diantara kita. Marilah kita bertahkim dengan kitabullah. Kemudian Ali mendapat desakan dari pimpinan-pimpinan pasukannya agar mau menerima ajakan tersebut sehingga pun tidak bisa berbuat apa-apa selain mengabulkan permintaannya untuk menerima.

Sebagai realisasi dari diterimanya perjanjian tersebut dalam Encyclopedie of Islam yang isinya sebagai berikut: "suatu perjanjian telah direncanakan di Siffin pada Safar $37 \mathrm{H} / 657 \mathrm{M}$. dan telah ditunjukkan dan dijelaskan dalam tahkim itu dua orang sebagai perantara yaitu Abu Musa al-Asy'ari dan Ali dan Amr Ibnu alAsy untuk Mu'awiyah yang akan mengumumkan keputusan mereka pada tempat yang mereka telah tentukan yaitu di tengah antara Syiria dan Iraq". Tetapi sebagaian di antara pasukan Sayyidina Ali ada yang tidak suka menerima ajakan tahkim itu, karena mereka menganggap bahwa orang yang mau berdamai ketika pertempuran adalah orang yang ragu akan pendiriannya dalam kebenaran peperangan yang ditegakkannya. Hukum Allah sudah nyata kata mereka. Siapa yang melawan Khalifah yang sah harus diperangi. "kita berperang guna menegakkan kebenaran demi keyakinan kepada agama kita. Kenapa kita mau 
berhenti perang sebelum mereka kalah", kata mereka. Akhirnya kaum ini membenci Ali r.a. karena dianggap lemah dalam menegakkan kebenaran, sebagaimana mereka membenci Mu'awiyah karena melawan Khalifah yang sah. Kaum inilah yang dinamakan Khawarij, kaum yang keuar dan memisahkan diri dari Ali. ${ }^{10}$

Berdasarkan keterangan di atas dapat difahami bahwa timbulnya Khawarij adalah persoalan politik yang berubah kemudian menjadi soal kepercayaan atau dogmatis teologi. Mereka menuduh Khalifah Ali bin Abi Thalib lebih percaya pada putusan musuh dan mengenyampingkan putusan Allah yaitu menerima tahkim yang menjadi sebab perpecahan dan perbedaan pendapat sampai tingkat dogmatis teologi.

Jadi, setelah menerima prinsip arbitrase yang merugikan pihak Ali, sebagian pengikut-pengikutnya keluar dari golongan Ali dan menamakan diri mereka dengan golongan Khawarij dan merupakan sekte pertama lahir dalam Islam. Mereka menentang arbitrase dengan prisip la hukma Illa Lillah. ${ }^{11}$

Nabi Muhammad SAW telah mengabarkan akan keluarnya kelompok ini di tengah-tengah umatnya. Telah diriwayatkan hadits-hadits secara mutawatir tentangnya. Sebagiannya disebutkan oleh al-Hafizh Ibnu Katsir, lebih dari tiga puluh hadits dalam kitabkitab Shahiih, Sunan dan kitab-kitab Musnad.

Di antaranya adalah hadits yang diriwayatkan oleh Abu Sa'id al-Khudri Radhiyallahu anhu, dia berkata, "Rasulullah Shallallahu 'alaihi wa sallam bersabda:

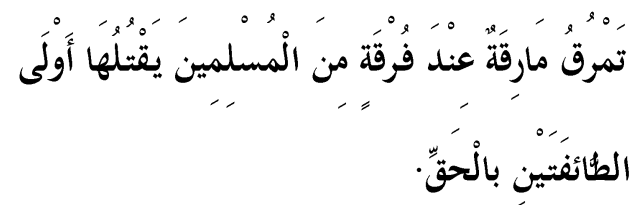

'Akan memisahkan diri satu kelompok (Khawarij) ketika kaum muslimin berpecah belah. Kelompok itu akan diperangi oleh salah satu golongan dari dua golongan yang lebih dekat dengan kebenaran.'" [HR. Muslim]

Dari Abu Sa'id Radhiyallahu anhu bahwasanya ketika beliau ditanya tentang al-Haruriyyah, beliau menjawab, "Aku tidak tahu apa al-Haruriyyah itu? Aku mendengar Nabi Shallallahu 'alaihi wa sallam bersabda:

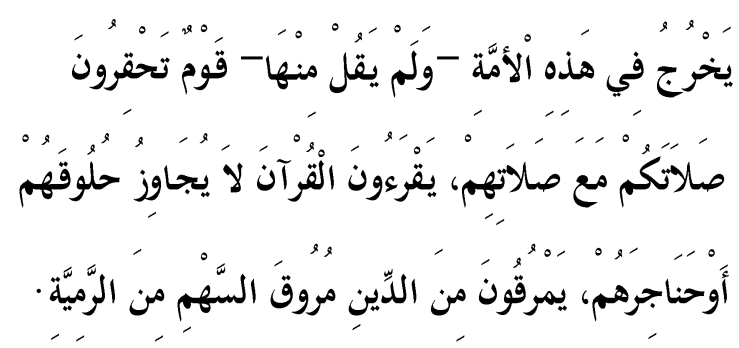

"Akan keluar di dalam umat ini -beliau tidak mengatakan di antaranya- suatu kaum yang kalian menganggap remeh 
shalat kalian dibandingkan shalat mereka, mereka membaca al-Qur-an namun tidak melewati kerongkongan mereka, mereka keluar dari agama bagaikan anak panah yang keluar dari busurnya." [HR. AlBukhari]

Nabi Muhammad SAW telah memerintahkan untuk memerangi kelompok Khawarij, dan beliau menjelaskan bahwa dalam memerangi mereka terdapat pahala dan ganjaran bagi orang yang membunuh mereka. Hal ini merupakan dalil kesesatannya kelompok ini dan jauhnya mereka dari Islam, juga bahayanya yang besar terhadap umat ini disebabkan fitnah dan kekacauan yang ditimbulkan oleh mereka. ${ }^{12}$

\section{E. Ajaran Pokok Aliran Khawarij}

Ajaran-ajaran pokok firqoh Khawarij ialah khilafah, dosa, dan imam. Pandangan firqoh Khawarij terdapat khalifah Sayyidina Ali dan Mu'awiyah adalah: "Asal mula ajaran Khawarij adalah hal-hal yang berkaitan dengan khalifah.mereka berpendapat sahnya khalifah Abu Bakar dan Umar. Karena sahnya pemilihan keduanya, dan sahnya khalifah Utsman pada beberapa tahun awal pemerintahannya. Tatkala dia berubah dan menyimpang kebijakannya dan tidak mengikuti jejak Abu Bakar dan Umar, dan berbuat hal-hal yang telah diperbuatnya (menyimpang), maka dia wajib dipecat. Mereka mengakui sahnya khalifah Ali, tetapi selanjutnya mereka berpendapat bahwa dia bersalah dalam masalah tahkim.mereka menghukuminya kafir karena menerima tahkim. Mereka juga mengutuk (mengkafirkan pengikut) orang-orang yang terlibat perang jamal: Thalhah, Zubair, dan Aisyah, sebagaimana pula mereka mengkafirkan Abu Musa Al-Asy'ari, dan Amr bin Ash."

Dosa yang ada hanyalah dosa besar saja,tidak ada pembagian dosa besar dan dosa kecil. Semua pendurhaka terhadap Allah SWT adalah berakibat dosa besar. Latar belakang Khawarij menetapkan dosa itu hanya satu macamnya, yaitu hanya dosa besar saja, agar orang Islam yang tidak sejalan dengan pendiriannya dapat diperangi dan dapat dirampas harta bendanya, dengan dalih mereka berdosa dan setiap yang berdosa adalah kafir.

Sekalipun asal mula gerakan khawarij itu masalah politik semata, namun kemudian berkembang menjadi corak keagamaan. Mereka berwatak keras, tanpa perhitungan taktik strategi, tanpa berpikir panjang atas kekuatan yang ada padanya sendiri dan kekuatan yang ada pada pihak lawan. Kemudian menurut golongan Khawarij iman itu bukan hanya membenarkan dalam hati dan ikrar lisan saja tetapi amal ibadah menjadi bagian 
dari iman.barang siapa tidak mengamalkan ibadah (amal bil arkan) seperti sholat, puasa, zakat, dan lain-lain, maka kafirlah dia. ${ }^{13}$

Adapun menurut pendapat lain bahwa pokok-pokok ajaran Khawarij dibagi menjadi tiga bidang yaitu:

\section{Di bidang Teologi}

a. Orang mukmin yang berbuat dosa besar (murtakib al-kaba'ir atau capital sinner) adalah kafir dan telah keluar dari Islam dan wajib dibunuh.

b. Ibadah termasuk rukun iman, maka orang yang tarikush shalat dinyatakan kafir.

c. Anak-anak orang kafir yang mati waktu kecilnya juga masuk neraka.

\section{Dalam bidang ketatanegaraan}

Kaum Khawarij lebih bersifat demokratis karena syarat untuk menjadi pemimpin umat (imam atau khalifah) tidak harus dari ahlul bait Rosulullah dan berbangsa Quraisy. Siapapun bisa, asal disepakati bersama. Hanya saja ada syarat kualitas kepribadian, yakni harus seoraang yang wira'i. zuhud, taqwa, tidak berbuat dosa dan kesalahan. Boleh tidak mematuhi aturan-aturan kepala Negara bila ternyata ia seorang yang dhalim.
Menurut Asy'ari yang dianggap kafir oleh khawarij ialah; Ali, Usman, yang ikut perang jamal, dan pelaku tahkim, yang menerima tahkim dan yang membenarkan tahkim maka wajib meninggalkan dari penguasa yang yang dhalim. ${ }^{14}$

\section{F. Sekte - Sekte Khawarij}

Khawarij pada umumnya terdiri dari orang-orang Arab Badui yang hidup sederhana di padang pasir yang tandus, bersifat keras hati dan berani dan merdeka tidak tergantung pada orang lain. Diantara sekte yang terkenal dalam kaum khawarij yaitu:

\section{Kaum Al-Muhakimmah}

Sekte Al Muhakimmah merupakan generasi pertama dan terdiri dari pengikut ali dalam perang shifin, mereka kemudian keluar dari barisan Ali dan berkumpul di Harurah dekat Khufah untuk menyusun kekuatan guna melakukan pemberontakan terhadap ali bin abi thalib. Mereka disebut Al Muhakimmah sesuai dengan prinsip dari golongan mereka: la hukma illa Allah'15 (tidak ada hukum selain hukum Allah) dengan prinsip tersebut, mereka berpandangan tidak sah menetapkan hukum selain hukum Allah yaitu Alquran. 
Menurut ajaran Muhakimmah semua orang yang melakukan dosa besar termasuk kafir. Sedangkan yang mereka maksudkan dengan dosa besar tersebut adalah berzina dan membunuh tanpa sebab.

\section{Al Azariqah}

Pemberian nama sekte ini dinisbahkan pada pendirinya Abi Rasyid Nai bin al Azraq.menurut para ahli sejarah sekte ini dikenal paling ekstrim dan radikal dari pada sekte lainnya dikalangan khawarij. Hal ini ditandai dengan dipergunakannya term musyrik bagi orang yang melakukan dosa besar sedangkan sekte lain hanya menggunakan term kafir. Term musyrik dalam Islam merupakan dosa yang paling besar melebihi dosa kafir.

\section{Al Najdah}

Nama sekte ini berasal dari nama pemimpinnya Najdah bin Amir Al Hanafi. Sekte ini merupakan sepaham dengan Al Azariqah karena mereka tidak setuju dengan term musyrik yang diberikan kepada orang yang tidak mengikuti paham Al Azariqah dan halal dibunuhnya perempuan dan anak-anak orang Islam yang tidak sepaham dengan mereka dengan alasan musyrik.

\section{Al Ajaridah}

Ajaridah adalah pengikut Adul Karim bin Ajrad. Menurut mereka hijrah bukan merupakan kewajiban tetapi kebajikan sehinggga bila pengikutnya tinggal diluar kekuasaan mereka tidak dianggap kafir.

\section{Ash Sufriyah}

Sekte ini adalah pengikut Ziyad bin Al Ashfar. Menurut kelompok ini orang yang melakukan dosa besar dikenakan had sebagaimana yang telah ditentukan oleh Allah. Seperti pencuri, pezina dan sebagainya. Sedangkan peaku dosa besar yang tidak ada hadnya maka disebut kafir namun demikian ada yang berpendapat bahwa pelaku dosa besar yang tidak ada hadnya tidak boleh dikafirkan kecuali atas keputusan hakim.

\section{Al Ibadiyah}

Aliran ini dipimpin oleh 'Abdullah ibn Ibadh. Mereka merupakan penganut paham Khawarij yang paling moderat dan luwes serta paling dekat dengan paham Sunni. Sehingga aliran ini masih bertahan sampai sekarang. ${ }^{16}$

Beberapa pendapat mereka yang menonjol adalah:

a) Orang Islam yang berbeda paham dengan mereka bukan orang musyrik, tetapi juga bukan orang mu'min. 
Mereka menamakannya dengan orang kafir, akan tetapi bukan kafir dalam hal keyakinan, karena orang tersebut tidak mengingkari adanya Allah swt.

b) Haram memerangi orang yang tidak sepaham dengan aliran Ibadhiyyah, dan wilayah mereka adalah wilayah tauhid dan Islam, kecuali wilayah pasukan tentara pemerintah. Akan tetapi mereka menyembunyikan pendapat itu.

c) Harta rampasan dari kaum muslimin yang menjadi lawan mereka haram diambil, kecuali kuda, senjata dan perlengkapan peranng lainnya, sedangkan emas dan perak harus dikembalikan.

d) Orang yang berbeda pendapat dengan Ibadhiyyah dapat menjadi saksi dalam suatu perkara, boleh menikahi mereka, serta saling mewarisi antara mereka dan penganut Khawarij lainnya tetap berlaku. ${ }^{17}$

\section{G. Kesimpulan}

Aliran Khawarij telah tumbuh dan berkembang dengan cara yang keras dan ekstrim dalam memahami ajaran Islam. Kehidupan dan lingkungan yang tidak begitu kondusif menjadikan mereka memahami ajaran Islam apa adanya tanpa ada usaha untuk memahami lebih lanjut tentang makna apa saja yang terkandung dalam wahyu Allah SWT.
Pengkafiran yang begitu mudah mereka lontarkan bagi orang-orang yang di luar paham mereka telah menyulut perpecahan bahkan pertumpahan darah yang tidak sedikit. Bagaimanapun Islam datang bukan sebagai sebuah aliran yang mengelompokkan manusia tapi lebih pada menyatukan manusia, tergantung pada masing-masing individu bagaimana memahami dan mengamalkanya. 


\section{Referensi}

${ }^{1}$ Harun Nasution, Teologi Islam, (Jakarta: Yayasan Penerbit Universitas Indonesia, 1978), h.1.

2Amat Zuhri, Warna-Warni Teologi Islam (Ilmu Kalam), (Yogyakarta: Gama Media Yogyakarta, cetakan 1. 2008), h. 8.

3http://id.shvoong.com/socialsciences/sociology/2160989-mazhabkhawarij/\#ixzz1t2RvPkiy

${ }^{4}{ } b i d,$.

${ }^{5}$ Harun nasution, teologi Islam, Aliranaliran sejarah analisis perbandingan (Jakarta: UIPress, cetakan V, 1986), h.11.

6Mulyadi \& Bashori, Studi Ilmu Tauhid/ Kalam, (Malang: UIN Maliki Press (Aggota IKAPI, 2010), hlm.102-104.

7Harun Nasution, Islam Rasional: Gagasan dan Pemikiran, (Bandung: Penerbit Mizan Anggota IKPAI, cetakan V, 1998), hlm 124-125.

8Sahilun A. Nasir, Kiai Haji, Pemikiran Kalam (Teologi Islam), (Jakarta: PT Raja Grafindo Persada, 2010), h. 123.

${ }^{9}$ Mulyadi \& Bashori, Op.Cit, h. 100.

10Mulyadi \& Bashori, Ibid, h. 101-102.

${ }^{11}$ Mulyadi \& Bashori, Ibid, h. 104

12.https:/ / almanhaj.or.id/3204-6e-

munculnya-kaum-khawarij.htm

13Sahilun A. Nasir, Kiai Haji,Op.Cit, h. 131135.

14Mulyadi \& Bashori, Op.Cit, h. 107.

15Pernyataan ini yang mereka gemborgemborkan sebagai kata hak namun dengan katakata tersebut kebathilanlah yang dikendaki. Ali tidak bisa mnikuti jalan pikiran mereka, ... demikian penjelasan dalam Hasan Ibrahim Hasan, Sejarah dan Kebudayaan Islam, (Jakarta: Kalam Muliya, 2001), h. 187-188.

16Muhammad Ahmad, Tauhid Ilmu Kalam, (Bandung: Pustaka Setia, 1998), h.157-158.
17Imam Muhammad abu Zahrah, Aliran Politik dan 'Aqidah dalam Islam, Terjemahan Abd. Rahman Dahlan dan Ahmad Qarib dari tarikh alMadzahib al-Islamuyyah, (Jakarta: Logos, 1996), h. 8384. 